\title{
An application of fuzzy BWM for risk assessment in offshore oil projects
}

\author{
Reza Ketabchi ${ }^{\mathrm{a}}$ and M. R. Ghaeli ${ }^{\mathrm{a}}$
}

${ }^{a}$ School of Management, New York Institute of Technology, 1700 - 701 W Georgia St., Vancouver, BC V7Y 1 K8 Canada

CH R O N I C LE A B S T RACT

Article history:

Received: November 282018

Received in revised format: December 252018

Accepted: March 12019

Available online:

March 12019

Keywords:

Project management

Risk assessment

Offshore oil projects

\begin{abstract}
The purpose of this paper is to examine the existing risks for the offshore project and risk weighting using the fuzzy best worst method (FBWM). In offshore oil projects, we face six major risks. Each of these risks is divided into smaller risks leaving us to have a total of 34 risks. Some of these risks are internal and some are external risks. In this method, first, the experts of this field determined the best and the worst type of risk. Then, using the experts' opinions, the study compared the remaining risks with the two selected risks and the other weights are determined. In our survey, "Technical Risk and Project Execution" is the most important risk factor followed by "Political Risk and Sanctions", "Market risk", "Management risk", "Financial risk and currency fluctuations" and "Environmental risk".
\end{abstract}

(C) 2019 by the authors; licensee Growing Science, Canada.

\section{Introduction}

Oil is the vital force of modern economics and as countries are developing and refining, demand for oil is rising, significantly. Future oil demand is difficult to predict, but in general, it will be linked to the growth of industrial production. Similarly, countries with rapid economic growth are likely significantly increase their demands for oil. Specifically, countries like China and India are fast growing in growth domestic product (GDP). Between 1991 and 2001, China's average annual GDP growth was 9.8\% while annual growth in India was 5.4\% (The Economist, 2004). In future, it is generally expected that emerging economies, especially China and India, would consume more of the world's oil production. Energy, financial markets, and the economy all are clearly on the path to economic growth (Basher \& Sadorsky, 2006). Projects are subject to internal risks (financial, design, contract, construction, personal, contributors, and operational risks) and external risks (economic, social, political, legal, public, logistics and environmental risks). All risks may affect the cost, program, or quality of the projects in a negatively. Therefore, risk management should be well known and used as a coherent function of project management (Van Thuyet et al., 2007). Risk definition usually refers to uncertain events that may affect project success. At the expense, time or quality of the projects delivered by the project. The assessment of a hazard level in a project involves two aspects: the probability of occurrence of the events and the expectations of their effects, both in terms of uncertainty, inconsistency and subjectivity (Rodríguez et al., 2016). Understanding and 
managing risks in projects, especially large engineering projects, are challenging tasks. First, the risks should be divided into related categories such as the market demand, which includes financial and supply; completion: technical, construction and operational; institutional: legal, social acceptability, and sovereignty. Strategies for coping with predictable risks can be developed using management approaches where the risk control costs must match the expected benefits. However, most of the hazards and controls should be considered as technical issues or as managerial problems (Miller \& Lessard, 2001). Offshore projects are also more environmentally vulnerable because the climate and maritime status are major sources of uncertainty and therefore require specific planning (Bowers \& Mould, 1994).

\section{Literature Review}

Projects often not delivered in time, or they suffer risk through increased costs due to inappropriate and indirect management. Causes of failure (risk factors) can be within the project or can be embedded in the external environment. Some of these are controllable, and others may be uncontrollable. Different types of risks require various strategies to reduce. They cannot be eliminated and we may only reduce their effects. Controlled ones can be damaged in the sprout and must be prevented from the source (Sharma, 2013). Using the various risk management tools and techniques, inefficiencies are increasingly managed. However, the use of these tools depends on the nature of the project, the organization's policy, the project management strategy, the attitude towards the project team's policy and access to resources (Dey \& Ogunlana, 2004). Due to the different importance of criteria in evaluating risks, several multi-criteria decision making techniques can be adopted to determine the weights of the criteria. Fuzzy synthetic evaluation approach can be applied to obtain the evaluation of each risk and a risk index calculated to indicate the level of each risk. This approach can also assess the overall risk level of the whole project by applying similar procedures (Liu et al., 2013). The increasing complexity and dynamism of projects have imposed substantial uncertainties and subjectivities in the risk analysis process. Most of the real-world risk analysis problems contain a mixture of quantitative and qualitative data; therefore quantitative risk assessment techniques are inadequate for prioritizing risks (Nieto-Morote \& Ruz-Vila, 2011). Fuzzy risk assessment provides a promising tool to quantify risk ratings where the risk impacts are vague and defined by subjective judgments rather than objective data (Dikmen et al., 2007). Project risk management tries to complete the project management activities by completing the project structure, organizational environment, external environment, products, processes and processes. Additionally, existing knowledge complemented by learning, best practices, industry benchmarks, and case studies which include risk reduction programs exist in case of occurrence of risk events. This prevents critical situations and future opportunities (Ahmed et al., 2007).

\section{Best Worst method}

The Best Worst method (BWM) proposed by Rezaei et al. (2015) is a new and powerful multi criteria decision making (MADM) technique for determining the subjective weights of criteria. In this method, the best (for example, the most desirable) and the worst criterion (for example, least desirable) are initially determined by decision makers. All criteria compared with the best and the worst criteria. Next we calculate the weights of the other criteria based on a linear programming model. For comparative systems that are not fully compatible with more than three standards, optimal solutions are obtained (Rezaei, 2015). With respect to BWM, decision making (DM)'s preferences are sensitive to the importance of precise weight when DM uses a natural language such as "much better", "somewhat worse" or "much better" to express a general setting. In this section, we develop the proposed BWM method for a bad DM behavior. In fact, using the proposed FBWM, explicit preferences in BMW, as triangular fuzzy numbers, to expose the inherent ambiguity of DM judgments in real-world decision-making problems is used (Hafezalkotob \& Hafezalkotob, 2017).

\section{The FBWM}

Step 1. Specify a set of decision criteria. 
In this step, we should determine the criteria set (Van Thuyet et al., 2007) that affects the decisionmaking process.

Step 2. Identify the best (i.e., the most favorable or significant) and the worst (i.e., the least favorable Or significant) criteria

Step 3.Specify the fuzzy preference degree of the best criterion $B$ over each criterion $j$ utilizing a triangular fuzzy number $\mathrm{a}_{\mathrm{BW}}=\left(\mathrm{a}_{\mathrm{BW}}^{\mathrm{L}}, \mathrm{a}_{\mathrm{BW}}^{\mathrm{M}}, \mathrm{a}_{\mathrm{BW}}^{\mathrm{U}}\right)$. Note that if $\mathrm{a}_{\mathrm{Bj}}^{\mathrm{U}}-\mathrm{a}_{\mathrm{Bj}}^{\mathrm{L}}=0$, then the preference or judgment would be non-fuzzy, such as the BWM (Rezaei, 2015). The fuzzy Best-to-Others vector of criteria preference degree would be:

$A_{B}=\left(a_{B 1}, a_{B 2} \ldots, a_{B n}\right)$

Step 4. Specify the fuzzy preference degree of each criterion j over the worst criterion $W$ utilizing a triangular fuzzy number $\mathrm{a}_{\mathrm{JW}}=\left(\mathrm{a}_{\mathrm{JW}}^{\mathrm{L}}, \mathrm{a}_{\mathrm{JW}}^{\mathrm{M}}, \mathrm{a}_{\mathrm{JW}}^{\mathrm{U}}\right)$. The fuzzy Others-to-Worst vector of criteria Preference degree would be:

$$
A_{W}=\left(a_{1 w}, a_{2 W} \ldots, a_{n W}\right)^{T}
$$

Step 5. Compute the optimal weights of criteria $\left(\mathrm{W}_{1}^{*}, \mathrm{~W}_{2}^{*} \ldots, \mathrm{W}_{\mathrm{n}}^{*}\right)$

Consider the fuzzy preferences $A_{B}$ and $A_{w}$, it is desired to determine the weights such that $\frac{W_{B}}{w_{J}}=$ $\mathrm{a}_{\mathrm{BJ}}$ and $\frac{\mathrm{W}_{\mathrm{J}}}{\mathrm{W}_{\mathrm{W}}}=\mathrm{a}_{\mathrm{JW}}$ for all J. The weights satisfying these conditions can be obtained by minimizing the maximum absolute differences $\left|\frac{\mathrm{w}_{\mathrm{B}}}{\mathrm{W}_{\mathrm{J}}}-\mathrm{a}_{\mathrm{BJ}}\right|$ and $\left|\frac{\mathrm{w}_{\mathrm{J}}}{\mathrm{W}_{\mathrm{W}}}-\mathrm{a}_{\mathrm{JW}}\right|$ for all J.

Regarding the common conditions for weights normalization, the optimal weights can be achieved by solving the following nonlinear programming problem:

$$
\begin{aligned}
& \min \max \left\{\left|\mathrm{W}_{\mathrm{B}}-\mathrm{a}_{\mathrm{BJ}} \mathrm{W}_{\mathrm{J}}\right|\right\},\left\{\left|\mathrm{W}_{\mathrm{J}}-\mathrm{a}_{\mathrm{JW}} \mathrm{W}_{\mathrm{W}}\right|\right\} \\
& \text { subject to } \\
& \sum_{\mathrm{J}} \mathrm{W}_{\mathrm{J}}=1 \\
& \mathrm{~W}_{\mathrm{J}} \geq 0, \text { For all } \mathrm{J}
\end{aligned}
$$

Problem (1) can rewritten into the following linear programming model:

$\min \in$

subject to

$$
\begin{aligned}
& \left\{\left|\mathrm{W}_{\mathrm{B}}-\mathrm{a}_{\mathrm{BJ}} \mathrm{W}_{\mathrm{J}}\right|\right\} \leq \in, \text { For all } \mathrm{J} \\
& \left\{\left|\mathrm{W}_{\mathrm{J}}-\mathrm{a}_{\mathrm{JW}} \mathrm{W}_{\mathrm{W}}\right|\right\} \leq \in, \text { For all } \mathrm{J} \\
& \sum_{\mathrm{J}} \mathrm{W}_{\mathrm{J}}=1 \\
& \mathrm{~W}_{\mathrm{J}} \geq 0, \text { For all } \mathrm{J}
\end{aligned}
$$

In problem (2), the symbol $\leq$ represents 'almost lesser than' constraint and enables us to consider some degree of "smaller" condition with regard to fuzzy values $\mathrm{a}_{\mathrm{BJ}} \mathrm{anda}_{\mathrm{JB}}$. Problem (2) is equivalent to the following problem: 
$\min \in$

subject to

$\mathrm{W}_{\mathrm{B}}-\epsilon \leq \mathrm{a}_{\mathrm{BJ}} \mathrm{W}_{\mathrm{J}}$, For all $\mathrm{J}$

$\mathrm{W}_{\mathrm{B}}+\in \geq \mathrm{a}_{\mathrm{BJ}} \mathrm{W}_{\mathrm{J}}$, For all $\mathrm{J}$

$\mathrm{W}_{\mathrm{J}}-\in \leq \mathrm{a}_{\mathrm{JW}} \mathrm{W}_{\mathrm{W}}$, For all $\mathrm{J}$

$\mathrm{W}_{\mathrm{J}}+\in \geq \mathrm{a}_{\mathrm{JW}} \mathrm{W}_{\mathrm{W}}$, For all $\mathrm{J}$

$\sum_{\mathrm{J}} \mathrm{W}_{\mathrm{J}}=1$

$\mathrm{W}_{\mathrm{J}} \geq 0$, For all $\mathrm{J}$

Considering the crisp equivalents of the fuzzy constraints in Problem (3), the problem can converted into the following optimization problem:

$\min \epsilon$

subject to

$\mathrm{W}_{\mathrm{B}}-\in \leq\left[\mathrm{a}_{\mathrm{BJ}}^{\mathrm{M}}+(1-\mathrm{a}) \mathrm{a}_{\mathrm{BJ}}^{\mathrm{U}}\right] \mathrm{W}_{\mathrm{J}}$, For all $\mathrm{J}$

$\mathrm{W}_{\mathrm{B}}+\in \geq\left[\mathrm{a}_{\mathrm{BJ}}^{\mathrm{M}}-(1-\mathrm{a}) \mathrm{a}_{\mathrm{BJ}}^{\mathrm{L}}\right] \mathrm{W}_{\mathrm{J}}$, For all $\mathrm{J}$

$\mathrm{W}_{\mathrm{J}}-\in \leq\left[\mathrm{a}_{\mathrm{Jw}}^{\mathrm{M}}+(1-\mathrm{a}) \mathrm{a}_{\mathrm{Jw}}^{\mathrm{U}}\right] \mathrm{W}_{\mathrm{w}}$, For all $\mathrm{J}$

$\mathrm{W}_{\mathrm{J}}+\in \geq\left[\mathrm{a}_{\mathrm{Jw}}^{\mathrm{M}}-(1-\mathrm{a}) \mathrm{a}_{\mathrm{Jw}}^{\mathrm{L}}\right] \mathrm{W}_{\mathrm{w}}$, For all $\mathrm{J}$

$\sum_{\mathrm{J}} \mathrm{W}_{\mathrm{J}}=1$

$\mathrm{W}_{\mathrm{J}} \geq 0$, For all $\mathrm{J}$

where a $(0 \leq \mathrm{a} \leq 1)$ represents a predefined possibility level by DM. Since the problem (4) is a linear programming problem, solving the problem for a given possibility level $a$ results in unique optimal weight $\left(\mathrm{W}_{1}^{*}, \mathrm{~W}_{2}^{*} \ldots, \mathrm{W}_{\mathrm{n}}^{*}\right)$ and $\epsilon^{*}$.

If $\in=0$ for all $a$, we have $\frac{\mathrm{w}_{\mathrm{B}}}{\mathrm{w}_{\mathrm{j}}}=\mathrm{a}_{\mathrm{BJ}}$ and $\frac{\mathrm{w}_{\mathrm{J}}}{\mathrm{w}_{\mathrm{w}}}=\mathrm{a}_{\mathrm{JB}}$ (and equivalently $\mathrm{a}_{\mathrm{BJ}} * \mathrm{a}_{\mathrm{JW}}=\mathrm{a}_{\mathrm{BW}}$

For all $\mathrm{j}$ ); thus, the fuzzy preferences $A_{B}$ and $A_{W}$ are fully consistent. Here, similar to the study of Rezaei (2015) the magnitude of $\in^{*}$ may represent consistency level of the fuzzy preference in Fig. 1.

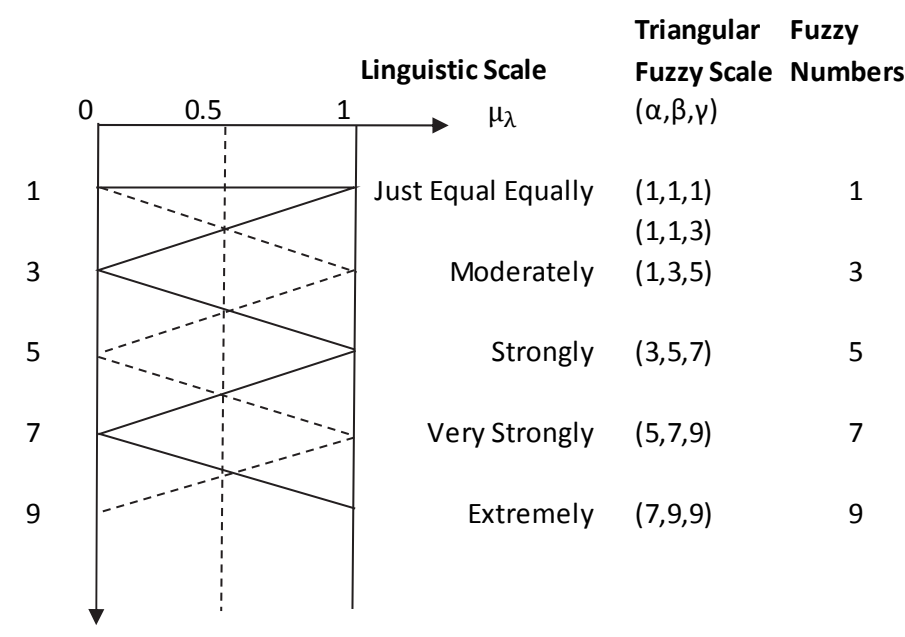

Fig. 1. Linguistic variables for the importance weight of each attribute (Turskis et al., 2015) 


\section{Types of Risks in Oil Projects}

In this article, we review six main risks that are important in oil projects.

\subsection{Technical Risk and Project Execution}

Technical risks result in non-performance, inefficiency of the product, non-conformance of the product to the customer's needs. Areas created by the technology used in the project or the project is working environment. For example, technical risks include design and product risks. The need for technology, complexity, performance, reliability and quality are also among these risks.(Armstrong et al. ,2004)

\subsection{Management Risk}

Failure to allocate time, cost, and appropriate work resources, use of inappropriate program, lack of adequate project management to achieve goals, communication and poor control, are examples of this group of risks (Van Thuyet et al., 2007). Management risk is divided into several categories:

- Risk of merit of the project manager in project management,

- The risk of the logic of the structure and infrastructure of the project,

- The risk of making scientific and effective decisions by the project manager,

- The risk of the existence of a scientific mechanism for the proper management of the project,

- The risk of frequent and unnecessary changes to the manager in long-term projects,

- The risk of early returns for project executives and the lack of long-term investment.

\subsection{Market risk}

An oil company or a company whose major assets are the shares of oil companies may consider an investment that is always faced with many risks, such as the risk of oil prices. In addition, depending on the degree of diversification of its activities, there are also risks of exploration and production (Cordesman \& Al-Rodhan, 2006). Market risk divided into several categories:

- Marketing risk and forecasting market demand for the product,

- Unbalanced pricing risk and loss of new businesses,

- Risk of prospective prospects for the production of new products,

- Risk of product competitiveness with other products on the market,

- Risk of potential competitors for the product,

- Risk of speed upgrading product technology,

- The risk of having a competitive market and the lack of market monopoly by the government,

- Risk of market weakness in order to sell the product.

\subsection{Financial risk and currency fluctuations}

In financial literature, the risk of exchange rate fluctuations is considered as one of the most important systematic risks. In fact, uncertainty about the amount of currency fluctuations for each business enterprise considered to a risk that could affect the financial flow of its activity. Hence, management of this risk is one of the important tasks of financial managers of these bonds (Salahor, 1998). Financial risk and currency fluctuations are divided into several categories:

- The risk of commodity price fluctuations, 
- Risk of exchange rate fluctuations,

- Risk of interest rate fluctuations,

- Risk of tax rate fluctuations,

- Risk of inflation,

- Risk of access to financial resources at the right time,

- Lack of support.

\subsection{Environmental risk}

Development, on one hand, is associated with industry and technology and, on the other hand, it is closely related to the degradation and pollution, yet it cannot be expected that the environment will remain untouched, along with industrial development, which is a prerequisite for the scientific and economic development of humankind. Today, environmental risk assessment is considered as an effective tool in environmental risk management studies of projects that have a high potential for degradation. Oil reserves are a huge constitution with oil wells, oil extraction and processing, but the construction of those platforms with high-risk can have significant environmental effects. Therefore, ongoing studies is needed (Stejskal, 2000). Environmental risk is divided into several categories:

- Risk of inappropriate policies in the industry,

- Risk of uncertainty about macroeconomic conditions in the country,

- The risk of instability of laws and regulations,

- The risk of environmental damage due to the implementation of the plan,

- Risk of having no standardization, technical assessment, and the problem of environmental and sanitary approval.

\subsection{Political Risk and Sanctions}

Foreign direct investment is a desirable form of capital entry to emergence and development because this investment is less for sudden crises and stagnation (Busse \& Hefeker, 2007). Although the risk of exchange rate fluctuations is one of the major risks for partners operating in the international arena, management is also one of the key components of financial management. In this case, the goal of minimizing losses is from fluctuations in exchange rates and the maximization of revenue from these fluctuations (Muller \& Verschoor, 2007). "Political Risk and Sanctions" is divided into several categories:

- The risk of changes in managers and authorities associated with supporting technology design and development,

- The risk of changing research priorities in policy and enforcement centers,

- Risk of international factors and global sanctions,

- Risk of relatively easy import of foreign goods,

- Risk of weakness of the business environment of the country for the development of emerging enterprises,

- Risk of non-coordination of government policy,

- Risk of lack of appropriate government policies to support plans. 
In order to identify the risk, a comprehensive database of alternatives and the causes of the occurrence of the risk and the effects of each of the risks on the operational and financial parts of the project should provide. This will make the project risks qualitatively turn into quantitative. Technique. It is also difficult to measure the success of the project due to the existence of different stakeholder criteria for assessing the success of the project. Therefore, the risks to projects should be identified and categorized (Lee et al., 2009).

After determining the criteria and indicators of the risk of oil and gas projects and in line with the main objective of the research, determining the importance and weights of each of the risks is carried out. At this stage, a questionnaire containing 6 main risks of oil and gas projects was completed by 10 experts and managers of oil and gas projects with over 15 years of job experience in this field. Note that professors have confirmed the validity and reliability of the questionnaire. We then solved the problem by using the Lingo software and the FBWM model, and the following results obtained and $\epsilon=0.2$. Table 1 summarizes the results of our survey.

\section{Table 1}

The summary of the results of ranking using FBWM

\begin{tabular}{clc}
\hline Parameter & Variable & Value \\
\hline W1 & Technical Risk and Project Execution & 0.3338334 \\
W2 & Market risk & 0.1477776 \\
W3 & Management Risk & 0.1420915 \\
W4 & Political Risk and Sanctions & 0.1574439 \\
W5 & Financial risk and currency fluctuations & 0.1420915 \\
W6 & Environmental risk & 0.0767621 \\
\hline
\end{tabular}

According to the experts' opinion, Technical Risk and Project Execution risk are considered as the best and environmental risks are selected as the worst risk, and the remaining risks assessed and ranked against these two risks. According to the results of Table 1, "Technical Risk and Project Execution" is the most important risk factor followed by "Political Risk and Sanctions", "Market risk", "Management risk", "Financial risk and currency fluctuations" and "Environmental risk".

Note that risks associated with the environment is in the lowest priority for the purpose of the case study of this paper but from one case to another, this risk may become more important.

\section{Conclusion}

There are many risks in offshore oil projects. Some are internal and can be controlled internally, but some of them require coordination and interaction outside the organization. The greatest risk is between the risks of offshore project Technical Risk and Project Execution. Offshore projects are of great importance due to their high level of difficulty and high technology for implementation and marine conditions, which, in terms of implementation, are risky and due to unpredictable circumstances. Subsequent Political Risk and Sanctions, market risk, management risk, financial risk and currency fluctuations and environmental risk are other risk involved with offshore oil projects and we need to pay attention to them as well.

\section{References}

Ahmed, A., Kayis, B., \& Amornsawadwatana, S. (2007). A review of techniques for risk management in projects. Benchmarking: An International Journal, 14(1), 22-36.

Armstrong, M., Galli, A., Bailey, W., \& Couët, B. (2004). Incorporating technical uncertainty in real option valuation of oil projects. Journal of Petroleum Science and Engineering, 44(1-2), 6782.

Basher, S. A., \& Sadorsky, P. (2006). Oil price risk and emerging stock markets. Global finance journal, 17(2), 224-251.

Bowers, J. A., \& Mould, G. I. (1994). Weather risk in offshore projects. Journal of the Operational Research Society, 45(4), 409-418.. 
Busse, M., \& Hefeker, C. (2007). Political risk, institutions and foreign direct investment. European journal of political economy, 23(2), 397-415.

Cordesman, A. H., \& Al-Rodhan, K. R. (2006). The global oil market: risks and uncertainties (No. 28). CSIS.

Dey, P. K., \& Ogunlana, S. O. (2004). Selection and application of risk management tools and techniques for build-operate-transfer projects. Industrial Management \& Data Systems, 104(4), 334-346.

Dikmen, I., Birgonul, M. T., \& Han, S. (2007). Using fuzzy risk assessment to rate cost overrun risk in international construction projects. International journal of project management, 25(5), 494-505.

Hafezalkotob, A., \& Hafezalkotob, A. (2017). A novel approach for combination of individual and group decisions based on fuzzy best-worst method. Applied Soft Computing, 59, 316-325.

Lee, E., Park, Y., \& Shin, J. G. (2009). Large engineering project risk management using a Bayesian belief network. Expert Systems with Applications, 36(3), 5880-5887..

Liu, J., Li, Q., \& Wang, Y. (2013). Risk analysis in ultra deep scientific drilling project—A fuzzy synthetic evaluation approach. International Journal of Project Management, 31(3), 449-458.

Miller, R., \& Lessard, D. (2001). Understanding and managing risks in large engineering projects. International Journal of Project Management, 19(8), 437-443.

Muller, A., \& Verschoor, W. F. (2007). Asian foreign exchange risk exposure. Journal of the Japanese and International Economies, 21(1), 16-37.

Nieto-Morote, A., \& Ruz-Vila, F. (2011). A fuzzy approach to construction project risk assessment. International Journal of Project Management, 29(2), 220-231.

Rezaei, J. (2015). Best-worst multi-criteria decision-making method. Omega, 53, 49-57.

Rodríguez, A., Ortega, F., \& Concepción, R. (2016). A method for the evaluation of risk in IT projects. Expert Systems with Applications, 45, 273-285..

Salahor, G. (1998). Implications of output price risk and operating leverage for the evaluation of petroleum development projects. The Energy Journal, 19(1), 13-46.

Sharma, S. K. (2013). Risk management in construction projects using combined analytic hierarchy process and risk map framework. IUP Journal of Operations Management, 12(4), 23-53..

Stejskal, I. V. (2000). Obtaining approvals for oil and gas projects in shallow water marine areas in western Australia using an environmental risk assessment framework. Spill Science \& Technology Bulletin, 6(1), 69-76.

Van Thuyet, N., Ogunlana, S. O., \& Dey, P. K. (2007). Risk management in oil and gas construction projects in Vietnam. International journal of energy sector management, 1(2), 175-194. Turskis, Z., Zavadskas, E. K., Antucheviciene, J., \& Kosareva, N. (2015). A hybrid model based on fuzzy AHP and fuzzy WASPAS for construction site selection. International Journal of Computers Communications \& Control, 10(6), 113-128.

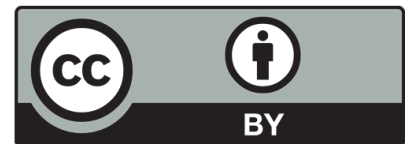

(C) 2019 by the authors; licensee Growing Science, Canada. This is an open access article distributed under the terms and conditions of the Creative Commons Attribution (CC-BY) license (http://creativecommons.org/licenses/by/4.0/). 